J. Dairy Sci. 92:790-798

doi:10.3168/jds.2008-1320

(c) American Dairy Science Association, 2009.

\title{
The addition of cottonseed hulls to the starter and supplementation of live yeast or mannanoligosaccharide in the milk for young calves
}

\author{
S. R. Hill, ${ }^{*}$ B. A. Hopkins, ${ }^{\star 1}$ S. Davidson, ${ }^{\star}$ S. M. Bolt, ${ }^{*}$ D. E. Diaz, ${ }^{\star}$ C. Brownie,† T. Brown,‡ \\ G. B. Huntington, ${ }^{\star}$ and L. W. Whitlow* \\ *Department of Animal Science, \\ †Department of Statistics, and \\ $\ddagger$ College of Veterinary Medicine, North Carolina State University, Raleigh 27695
}

\section{ABSTRACT}

The objectives of this study were to investigate the effects of the addition of cottonseed hulls (CSH) to the starter and the supplementation of live yeast product (YST) or mannanoligosaccharide product (MOS) to milk, on growth, intake, rumen development, and health parameters in young calves. Holstein $(\mathrm{n}=116)$ and Jersey $(\mathrm{n}=46)$ bull $(\mathrm{n}=74)$ and heifer $(\mathrm{n}=$ 88) calves were assigned randomly within sex at birth to treatments. All calves were fed $3.8 \mathrm{~L}$ of colostrum daily for the first $2 \mathrm{~d}$. Holstein calves were fed $3.8 \mathrm{~L}$ of whole milk, and Jersey calves were fed $2.8 \mathrm{~L}$ of whole milk through weaning at $42 \mathrm{~d}$. Calves continued on trial through 63 d. Six treatments were arranged as a $2 \times 3$ factorial. Calves received either a corn-soybean meal-based starter (21\% crude protein and 6\% acid detergent fiber; - $\mathrm{CSH})$ or a blend of $85 \%$ corn-soybean meal-based starter and 15\% CSH (18\% crude protein and $14 \%$ acid detergent fiber; $+\mathrm{CSH})$ ad libitum. In addition, calves received whole milk with either no supplement (NONE) or supplemented with $3 \mathrm{~g} / \mathrm{d}$ of mannanoligosaccharide product (MOS) or $4 \mathrm{~g} / \mathrm{d}$ of live yeast product (YST) through weaning at $42 \mathrm{~d}$. Twelve Holstein steers $[\mathrm{n}=6$ (per starter type); $\mathrm{n}=4$ (per supplement type)] were euthanized for collection and examination of rumen tissue samples. Dry matter intake (DMI) was greater for Holstein calves fed +CSH $(0.90$ $\mathrm{kg} / \mathrm{d})$ than $-\mathrm{CSH}(0.76 \mathrm{~kg} / \mathrm{d})$. Final body weight at $63 \mathrm{~d}$ of Holstein calves fed $+\mathrm{CSH}(75.8 \mathrm{~kg})$ was greater than that of those fed - CSH $(71.0 \mathrm{~kg})$. Average daily gain (ADG) was greater for Holstein calves fed $+\mathrm{CSH}$ $(0.58 \mathrm{~kg} / \mathrm{d})$ than $-\mathrm{CSH}(0.52 \mathrm{~kg} / \mathrm{d})$. However, Holstein calves fed - CSH had a greater feed efficiency (FE; 0.71 $\mathrm{kg}$ of $\mathrm{ADG} / \mathrm{kg}$ of DMI) than those fed $+\mathrm{CSH}(0.65 \mathrm{~kg}$ of $\mathrm{ADG} / \mathrm{kg}$ of DMI). Also, Holstein calves fed $+\mathrm{CSH}$ had narrower rumen papillae $(0.32 \mathrm{~mm})$ compared with

Received May 1, 2008.

Accepted September 30, 2008.

${ }^{1}$ Corresponding author: Brinton_Hopkins@ncsu.edu those fed $-\mathrm{CSH}(0.41 \mathrm{~mm})$. There were no significant effects of CSH on DMI, ADG, or FE in Jersey calves. There were no significant effects of YST or MOS on DMI, ADG, FE, or rumen papillae measures in Holstein calves. Jersey calves fed YST or MOS had greater final body weight at $63 \mathrm{~d}(51.2 \mathrm{~kg}$ and $51.0 \mathrm{~kg}$, respectively) than calves fed NONE $(47.5 \mathrm{~kg})$. However, there were no significant effects of YST or MOS on DMI, ADG, or FE in Jersey calves.

Key words: cottonseed hull, calf, yeast, mannanoligosaccharide

\section{INTRODUCTION}

Although protein and energy requirements for young calves have been published, requirements for fiber and its effects on growth, health, and rumen development are not clearly defined (NRC, 2001). The NRC (2001) recommends that calves be fed dry feed from an early age and suggests that long hay is not as beneficial to the development of rumen mucosa as are concentratetype starter diets with adequate concentrations of digestible fiber. Consumption of concentrate-type starter diets has been shown to increase VFA production in the calf, particularly butyrate, which is closely related to greater papillae development and subsequently related to growth of the whole animal (Stobo et al., 1966). Although feeding concentrate diets to calves improves ruminal epithelial development, forage or high-fiber feedstuffs increase rumen muscularization, volume, and motility (Heinrichs, 2005). Cottonseed hulls (CSH) provide added fiber and increased particle size to calf starter diets. Miller et al. (1969) reported greater DMI and ADG but lower feed efficiency (FE) in calves when $10 \%$ CSH was added to low-fiber starter diets. Van Horn et al. (1976) added CSH, citrus pulp, or both as fiber sources to calf starter diets and stated that feeding CSH resulted in greater DMI and ADG. Murdock and Wallenius (1980) fed calves 1 of 3 starter diets that contained similar fiber concentrations (16 to $18 \%$ $\mathrm{ADF}$ ) provided by $\mathrm{CSH}$, beet pulp, or alfalfa meal. As a 
result, calves fed CSH consumed more starter DM and gained more BW with no difference in FE (Murdock and Wallenius, 1980).

The addition of yeast cultures of Saccharomyces cerevisiae has been shown to alter fermentation products in the rumen of both cows and calves (Quigley et al., 1992a; Enjalberta et al., 1999). Lesmeister et al. (2004) supplemented a calf starter diet with $2 \%$ of a S. cerevisiae yeast culture and significantly increased ADG, DMI, and hip width in calves. Seymour et al. (1995) reported decreased incidence of elevated body temperatures in calves when $1 \%$ brewer's yeast was supplemented to a calf starter. Fonty and Chaucheyras-Durand (2006) suggested that performance and health benefits reported with yeast may be associated with improved growth and activity of fiber-degrading bacteria and fungi, stabilization of rumen $\mathrm{pH}$, prevention of lactate accumulation, improved ruminal microbial colonization, and the development of fermentation during the preweaning period. Furthermore, yeast may provide growth factors for rumen microorganisms, oxygen-scavenging compounds, or nutritional competition with other rumen microbes (Fonty and Chaucheyras-Durand, 2006).

Mannanoligosaccharides are a part of the carbohydrate fraction of the yeast cell wall. Spring et al. (2000) suggested that certain pathogenic bacteria can bind to mannanoligosaccharides in the digestive tract and prevent adhesion to the gut wall. Because mannanoligosaccharides are poorly digested, bacteria bound to them could be excreted in feces. Results from feeding mannanoligosaccharides have been variable, but some authors have shown benefits such as improved immune function in dogs (Swanson et al., 2002), improved FE in pigs (Burkey et al., 2004), and improved fecal scores in Holstein calves (Heinrichs et al., 2003). The objectives of this study were to investigate the effects of adding $\mathrm{CSH}$ to the starter and of supplementing live yeast or mannanoligosaccharide to whole milk, on growth, intake, rumen development, and health parameters in young calves.

\section{MATERIALS AND METHODS}

\section{Diets and Design}

Holstein $(\mathrm{n}=56)$ and Jersey $(\mathrm{n}=46)$ calves from the North Carolina State University Lake Wheeler Road Dairy Educational Unit (DEU) and Holstein $(\mathrm{n}=60)$ calves from the North Carolina Department of Agriculture Piedmont Research Station (PRS) were assigned randomly at birth to 1 of 6 treatments. The treatments were arranged as a $2 \times 3$ factorial.

Colostrum was fed from individual dams, unless unavailable, in which case stored frozen colostrum was fed. Colostrum was not analyzed for nutrient or Ig content. Blood samples were not obtained from the calves; therefore, no analysis for determination of passive transfer was conducted. All calves were fed 3.8 L of colostrum once daily for the first $2 \mathrm{~d}$. Based on body size, Holstein calves were fed $3.8 \mathrm{~L}$ of whole milk and Jersey calves were fed $2.8 \mathrm{~L}$ of whole milk through weaning at $42 \mathrm{~d}$. The average DHIA analysis for the milk from PRS for this time period was $3.59 \%$ fat and $2.93 \%$ protein. At PRS, only milk from cows identified as negative for the bovine leukosis virus was fed to the calves. The average DHIA analysis for the milk from DEU for this time period was $3.96 \%$ fat and $3.15 \%$ protein. Calves were fed once daily via nipple bottle with 1 of 3 treatments from $3 \mathrm{~d}$ through weaning at 42 d: no supplement (NONE), $3 \mathrm{~g} / \mathrm{d}$ of a mannanoligosaccharide product (MOS), or $4 \mathrm{~g} / \mathrm{d}$ of a live yeast product (YST). To ensure that the supplements were dissolved completely, $15 \mathrm{~mL}$ of warm water was mixed with the supplement in a nipple bottle before milk was added. Each supplement provided by the treatments was added to the milk at amounts recommended by the manufacturer (Saf-Agri Corp., Minneapolis, MN).

Calves also received 1 of 2 treatment starter diets: a corn-soybean meal-based starter (-CSH; $21 \% \mathrm{CP}$ and $6 \% \mathrm{ADF}$ ) or a blend of the same corn-soybean meal-based starter ( $85 \%$ as fed) and CSH ( $15 \%$ as fed) (+CSH; $18 \% \mathrm{CP}$ and $14 \% \mathrm{ADF}$; Table 1). Calves were offered treatment starter diets from d 1 through 63 and were given ad libitum access to water. Calves were offered $0.09 \mathrm{~kg} / \mathrm{d}$ of starter from $\mathrm{d} 1$. When there were no orts, the amount of starter offered was increased by $0.09 \mathrm{~kg} / \mathrm{d}$.

At birth, calves at DEU were housed and fed individually in outdoor hutches, and treatment assignments were balanced by breed and sex. Calves at PRS were housed and fed individually in either outdoor hutches (each with an attached outside fenced area) or pens in an open-sided barn. Outdoor hutches and the pens in the open-sided barn provided a similar amount of space (4.55 vs. $3.90 \mathrm{~m}^{2}$, respectively). Treatment assignments were balanced by housing type and sex. Bedding differed by location; a sand base covered with kiln-dried wood chips was used at PRS, and a gravel base covered with straw was used at DEU. All calves were dehorned at d 42, and all bull calves were castrated at d 14 approximately. Although calves were weaned at d 42, they remained in hutches or pens until $63 \mathrm{~d}$ of age.

\section{Sample Collection and Analysis}

Body weight, wither height, and hip width were measured weekly. Rectal temperatures, respiratory scores, and fecal scores were recorded daily (Larson et 
Table 1. Ingredient and nutrient composition of starter diets with or without cottonseed hulls fed to Holstein and Jersey calves

\begin{tabular}{|c|c|c|c|c|}
\hline \multirow[b]{2}{*}{ Item } & \multicolumn{2}{|c|}{ Starter $^{1}$} & \multirow[b]{2}{*}{ SEM } & \multirow[b]{2}{*}{$P<$} \\
\hline & $-\mathrm{CSH}$ & $+\mathrm{CSH}$ & & \\
\hline \multicolumn{5}{|l|}{ Ingredient, $\%$ of DM } \\
\hline Cottonseed hulls & 0 & 15.0 & & \\
\hline Corn grain, ground & 64.2 & 54.6 & & \\
\hline Soybean meal, $48 \%$ & 24.1 & 20.4 & & \\
\hline Soybean hulls & 5.10 & 4.40 & & \\
\hline Dried cane molasses & 4.10 & 3.40 & & \\
\hline Salt & 0.56 & 0.47 & & \\
\hline Dicalcium phosphate & 0.73 & 0.61 & & \\
\hline Calcitic limestone & 1.20 & 1.00 & & \\
\hline Vitamin-trace mineral premix ${ }^{2}$ & 0.06 & 0.05 & & \\
\hline \multicolumn{5}{|l|}{ Nutrient $^{3}$} \\
\hline DM, $\%$ of diet & 89.7 & 89.7 & 0.37 & 0.98 \\
\hline $\mathrm{CP}, \%$ of DM & 20.7 & 18.1 & 0.76 & 0.02 \\
\hline $\mathrm{NDF}, \%$ of DM & 25.8 & 38.6 & 1.32 & 0.01 \\
\hline $\mathrm{ADF}, \%$ of $\mathrm{DM}$ & 5.79 & 14.4 & 0.56 & 0.01 \\
\hline
\end{tabular}

${ }^{1}-\mathrm{CSH}=$ starter diet without cottonseed hulls; $+\mathrm{CSH}=$ starter diet with $15 \%$ cottonseed hulls.

${ }^{2}$ Vitamin-trace mineral premix contained $21.5 \% \mathrm{Ca}, 5.5 \% \mathrm{~S}, 3.87 \% \mathrm{Zn}, 3.87 \% \mathrm{Mn}, 1.18 \% \mathrm{Cu}, 9,650 \mathrm{mg} / \mathrm{kg}$ of Fe, $700 \mathrm{mg} / \mathrm{kg}$ of I, $590 \mathrm{mg} / \mathrm{kg}$ of Co, $250 \mathrm{mg} / \mathrm{kg}$ of Se, 1,215,420 IU $/ \mathrm{kg}$ of vitamin A, 304,545 IU $/ \mathrm{kg}$ of vitamin $\mathrm{D}_{3}$, and $3,646 \mathrm{IU} / \mathrm{kg}$ of vitamin $\mathrm{E}$.

${ }^{3}$ Analysis conducted with $\mathrm{n}=20$ samples per treatment diet.

al., 1977). Feed allocation was measured daily, sampled weekly, and composited monthly. Orts were weighed twice weekly, sampled weekly, and composited monthly. Average daily intakes were calculated from the difference of weekly feed allocations and orts. Feed and orts samples were analyzed for $\mathrm{DM}, \mathrm{CP}, \mathrm{NDF}$, and $\mathrm{ADF}$ (AOAC, 1990).

\section{Rumen Development Measures}

Twelve Holstein steers $[\mathrm{n}=6$ (per starter type); $\mathrm{n}$ $=4$ (per supplement type)] were euthanized at $63 \mathrm{~d}$ for collection and examination of rumen tissue samples according to the procedures of Hill et al. (2005). Five rumen tissue samples were collected from 4 regions of the rumen (dorsal, ventral, cranial, and caudal) for measurement of papillae width, length, and denseness. Surface area of a papilla $\left(\mathrm{cm}^{2}\right)$ was calculated as the area of a cylinder plus the area of a circle. Then, the surface area ratio (SAR) was calculated by multiplying the average surface area of the papillae in a section of the rumen by the average papillae denseness (number per $\mathrm{cm}^{2}$ ) in the same section (Hill et al., 2005).

Rumen fluid samples were collected from euthanized calves by straining rumen contents through double-layered cheesecloth into 50-mL collection tubes. Samples were placed on ice, measured for $\mathrm{pH}$ within $2 \mathrm{~h}$, and then frozen $\left(-20^{\circ} \mathrm{C}\right)$ for later VFA analysis. For VFA analysis, rumen fluid was thawed, centrifuged at 2,500 $\times g$ for $10 \mathrm{~min}$ at $4^{\circ} \mathrm{C}$, and the supernatant was collected. Then, $1 \mathrm{~mL}$ of $25 \%$ metaphosphoric acid with an internal standard was added to $5 \mathrm{~mL}$ of supernatant and centrifuged at room temperature (approximately $22^{\circ} \mathrm{C}$ ) for $15 \mathrm{~min}$ at $9,300 \times \mathrm{g}$. A $1-\mathrm{mL}$ aliquot was analyzed for VFA by gas chromatography (model CP3380, Varian, Walnut Creek, CA).

\section{Statistical Analysis}

The statistical model included starter ( $-\mathrm{CSH}$ or $+\mathrm{CSH}$ ), supplement (NONE, MOS, or YST), sex (bull or heifer), and location (DEU or PRS) as the main effects. All possible interactions were examined and removed from the model if not significant.

Data were analyzed within breed. A separate analysis of data from the DEU location was used to compare performance of Holsteins and Jerseys, because Jerseys were located at DEU only (Table 2).

Feed efficiency, ADG, health, and rumen measures were subjected to ANOVA using the GLM procedure (SAS Institute Inc., Cary, NC), and least squares means are reported. Remaining data with multiple measures per calf were analyzed by repeated measures ANOVA using the MIXED procedure of SAS, and least squares means are reported. Significance was declared at $P<$ 0.05 .

\section{RESULTS AND DISCUSSION}

\section{Intake, Growth, and Health Measurements}

Intake, growth, and health measurements are presented for Holstein calves (Table 3) and for Jersey calves 
Table 2. Performance comparison of Holstein and Jersey calves located at the North Carolina State University Lake Wheeler Road Dairy Educational Unit on an actual and metabolic BW $\left(\mathrm{BW}^{0.75}\right)$ basis

\begin{tabular}{lcccc}
\hline Item & Holstein $(\mathrm{n}=56)$ & Jersey $(\mathrm{n}=46)$ & SEM & $P<$ \\
\hline Average BW, $\mathrm{kg}$ & $53.5^{\mathrm{a}}$ & $36.6^{\mathrm{b}}$ & 0.9 & 0.01 \\
Starter DMI, $\mathrm{kg} / \mathrm{d}$ & $0.82^{\mathrm{a}}$ & $0.61^{\mathrm{b}}$ & 0.03 & 0.01 \\
Total DMI, ${ }^{\mathrm{b}} \mathrm{kg} / \mathrm{d}$ & $1.32^{\mathrm{a}}$ & $1.00^{\mathrm{b}}$ & 0.03 & 0.01 \\
Total DMI, $\%$ of BW & $2.3^{\mathrm{b}}$ & $2.6^{\mathrm{a}}$ & 0.1 & 0.01 \\
ADG, $\mathrm{kg} / \mathrm{d}$ & $0.49^{\mathrm{a}}$ & $0.39^{\mathrm{b}}$ & 0.02 & 0.01 \\
Average BW ${ }^{0.75}, \mathrm{~kg}$ & $19.7^{\mathrm{a}}$ & $14.8^{\mathrm{b}}$ & 0.2 & 0.01 \\
Total DMI, ${ }^{\mathrm{b}} \%$ of BW ${ }^{0.75}$ & 6.3 & 6.4 & 0.1 & 0.40 \\
ADG, ${ }^{3} \mathrm{~kg} / \mathrm{d}$ & $0.11^{\mathrm{a}}$ & $0.10^{\mathrm{b}}$ & 0.004 & 0.01 \\
Feed efficiency & & & & \\
ADG:starter DMI, ${ }^{1} \mathrm{~kg} / \mathrm{kg}$ & 0.64 & 0.64 & 0.02 & 0.98 \\
ADG:total DMI, ${ }^{\mathrm{kg}} / \mathrm{kg}$ & 0.41 & 0.40 & 0.02 & 0.94 \\
\hline
\end{tabular}

a,b Means within a row with different superscripts differ $(P<0.05)$.

${ }^{1}$ Starter DMI includes DMI from starter only.

${ }^{2}$ Total DMI includes DM consumed both in starter and whole milk (12.5\% DM assumed).

${ }^{3} \mathrm{ADG}$ calculated using $\mathrm{BW}^{0.75}$.

(Table 4) and are reported for the effects of starter type or supplement. There were no significant starter $x$ supplement interactions for intake, growth, and health measurements in Holstein or Jersey calves.

Starter Effects. The 2 starter diets were similar in DM content. The addition of CSH to the $+\mathrm{CSH}$ diet resulted in decreased $\mathrm{CP}$ (\% of DM), increased NDF (\% of DM), and increased ADF (\% of DM; Table 1). Crude protein intake was similar between the 2 treatment diets fed to Holsteins but was greater in Jerseys consuming $+\mathrm{CSH}$ (Tables 3 and 4). Intake of NDF and
ADF was greater for Holsteins and Jerseys fed $+\mathrm{CSH}$ than for those fed - CSH.

Holstein calves fed $+\mathrm{CSH}$ diets had greater BW at 49,56 , and $63 \mathrm{~d}$ compared with calves fed - CSH diets (Figure 1). Holsteins fed $+\mathrm{CSH}$ had greater starter DMI and ADG than those fed - CSH diets (Table 3). However, starter DMI and ADG were not different in Jerseys receiving $+\mathrm{CSH}$ or $-\mathrm{CSH}$ diets (Table 4). Therefore, ADG appeared to be related to intake. Although not measured in this study, gut fill may have contributed to increased ADG in Holstein calves fed $+\mathrm{CSH}$, but

Table 3. Intake, growth, and health measures in Holstein calves fed starter diets with or without cottonseed hulls and milk with or without supplements

\begin{tabular}{|c|c|c|c|c|c|c|c|c|c|}
\hline \multirow[b]{2}{*}{ Item } & \multicolumn{4}{|c|}{ Starter $^{1}$} & \multicolumn{5}{|c|}{ Supplement $^{2}$} \\
\hline & $\begin{array}{c}-\mathrm{CSH} \\
(\mathrm{n}=58)\end{array}$ & $\begin{array}{c}+\mathrm{CSH} \\
(\mathrm{n}=58)\end{array}$ & SEM & $P<$ & $\begin{array}{l}\text { NONE } \\
(\mathrm{n}=38)\end{array}$ & $\begin{array}{c}\text { MOS } \\
(\mathrm{n}=40)\end{array}$ & $\begin{array}{c}\text { YST } \\
(\mathrm{n}=38)\end{array}$ & SEM & $P<$ \\
\hline \multicolumn{10}{|l|}{ Starter intake } \\
\hline $\mathrm{DM}, \mathrm{kg} / \mathrm{d}$ & $0.76^{\mathrm{b}}$ & $0.90^{\mathrm{a}}$ & 0.03 & 0.01 & 0.86 & 0.82 & 0.81 & 0.04 & 0.59 \\
\hline $\mathrm{CP}, \mathrm{kg} / \mathrm{d}$ & 0.16 & 0.16 & 0.01 & 0.81 & 0.16 & 0.16 & 0.16 & 0.01 & 0.87 \\
\hline $\mathrm{NDF}, \mathrm{kg} / \mathrm{d}$ & $0.20^{\mathrm{b}}$ & $0.37^{\mathrm{a}}$ & 0.01 & 0.01 & 0.28 & 0.28 & 0.29 & 0.02 & 0.92 \\
\hline \multicolumn{10}{|l|}{ Growth measures } \\
\hline $\mathrm{ADG}, \mathrm{kg} / \mathrm{d}$ & $0.52^{\mathrm{b}}$ & $0.58^{\mathrm{a}}$ & 0.02 & 0.02 & 0.57 & 0.53 & 0.54 & 0.02 & 0.38 \\
\hline ADG:DMI, kg/kg & $0.71^{\mathrm{a}}$ & $0.65^{\mathrm{b}}$ & 0.02 & 0.03 & 0.70 & 0.66 & 0.68 & 0.03 & 0.45 \\
\hline Wither height, cm & 78.5 & 78.4 & 0.4 & 0.84 & 79.0 & 78.3 & 78.0 & 0.5 & 0.32 \\
\hline Hip width, cm & 21.7 & 21.7 & 0.2 & 0.77 & 21.8 & 21.8 & 21.5 & 0.2 & 0.48 \\
\hline \multicolumn{10}{|l|}{ Health measures } \\
\hline Fecal score ${ }^{3}$ & $1.34^{\mathrm{a}}$ & $1.25^{\mathrm{b}}$ & 0.03 & 0.03 & $1.32^{\mathrm{x}}$ & $1.28^{\mathrm{y}}$ & $1.29^{\mathrm{y}}$ & 0.03 & 0.01 \\
\hline Respiratory score ${ }^{4}$ & 1.05 & 1.03 & 0.01 & 0.69 & 1.04 & 1.04 & 1.04 & 0.02 & 0.86 \\
\hline
\end{tabular}


increased energy intake most likely accounted for the increase in ADG. The difference in DMI between Holstein calves fed $+\mathrm{CSH}$ and $-\mathrm{CSH}(0.90 \mathrm{~kg} / \mathrm{d}-0.76$ $\mathrm{kg} / \mathrm{d}$ ) was similar to the calculated amount of $\mathrm{CSH}$ consumed by calves fed $+\mathrm{CSH}(0.135 \mathrm{~kg} / \mathrm{d})$. Therefore, the increase in DMI in calves fed $+\mathrm{CSH}$ was primarily due to intake of $\mathrm{CSH}$ with a similar intake of other diet ingredients. This would result in increase in energy intake sufficient to support the observed increase in ADG of the calves fed $+\mathrm{CSH}$. In other studies, addition of $\mathrm{CSH}$ to calf starters has increased intake in comparison to starters with similar fiber concentrations (Murdock and Wallenius, 1980) or lower fiber concentrations (Miller et al., 1969), suggesting that CSH addition can increase intake regardless of fiber concentration. Van Horn et al. (1984) reported that cows fed CSH consumed more DM than would be predicted based on the dietary fiber content. Macleod et al. (1970) fed a starter that contained $20 \%$ hay and noted increased starter consumption, which they concluded was a result of the lower energy concentration of the starter.

For Holsteins, FE for calves fed + CSH was lower than that of those fed $-\mathrm{CSH}$, because DMI was greater (Table 3). For Jerseys, FE was not different as a result of starter type, and DMI was not different (Table 4). Wither height and hip width were not significantly affected by starter type for either Holstein or Jersey calves.

Holstein, but not Jersey, calves fed $+\mathrm{CSH}$ had a lower average fecal score than calves fed -CSH (Table 3). A lower fecal score indicated a lower incidence of diarrhea. Average body temperature and respiratory scores were not different between the $+\mathrm{CSH}$ and $-\mathrm{CSH}$ treatments for Holstein or Jersey calves.

Supplement Effects. The addition of supplements to milk did not affect starter DMI, CP intake, NDF intake, ADF intake, ADG, FE, wither height, or hip width in both Holsteins and Jerseys. There was no difference in BW of Holstein calves as a result of supplement addition to the milk. In contrast, Jersey calves that were fed either MOS or YST had a greater final BW (63 d) than those fed NONE (Figure 2). Heinrichs et al. (2003) observed no differences in BW, ADG, or other growth parameters when $4 \mathrm{~g} / \mathrm{d}$ of a mannanoligosaccharide product was added to the diet of Holstein calves. Lesmeister et al. (2004) reported that Holstein calves fed $2 \%$ yeast culture had greater BW and starter intake at $42 \mathrm{~d}$ of age than calves not receiving yeast, although there were no differences in $\mathrm{BW}$ at weaning (35 d of age).

Average fecal scores were lower for Holstein calves receiving MOS or YST compared with those receiving NONE. Jersey calves that received YST had a lower average fecal score than those that received NONE, but was not different from those that received MOS. Seymour et al. $(1995)$ reported a tendency $(P=0.07)$ for a lower percentage of days with scours for calves receiving $1 \%$ (of starter diet DM) brewer's yeast during d 12 to 25 of life. However, Lesmeister et al. (2004) did not see a significant effect on days scoured when adding

Table 4. Intake, growth, and health measures in Jersey calves fed starter diets with or without cottonseed hulls and milk with or without supplements.

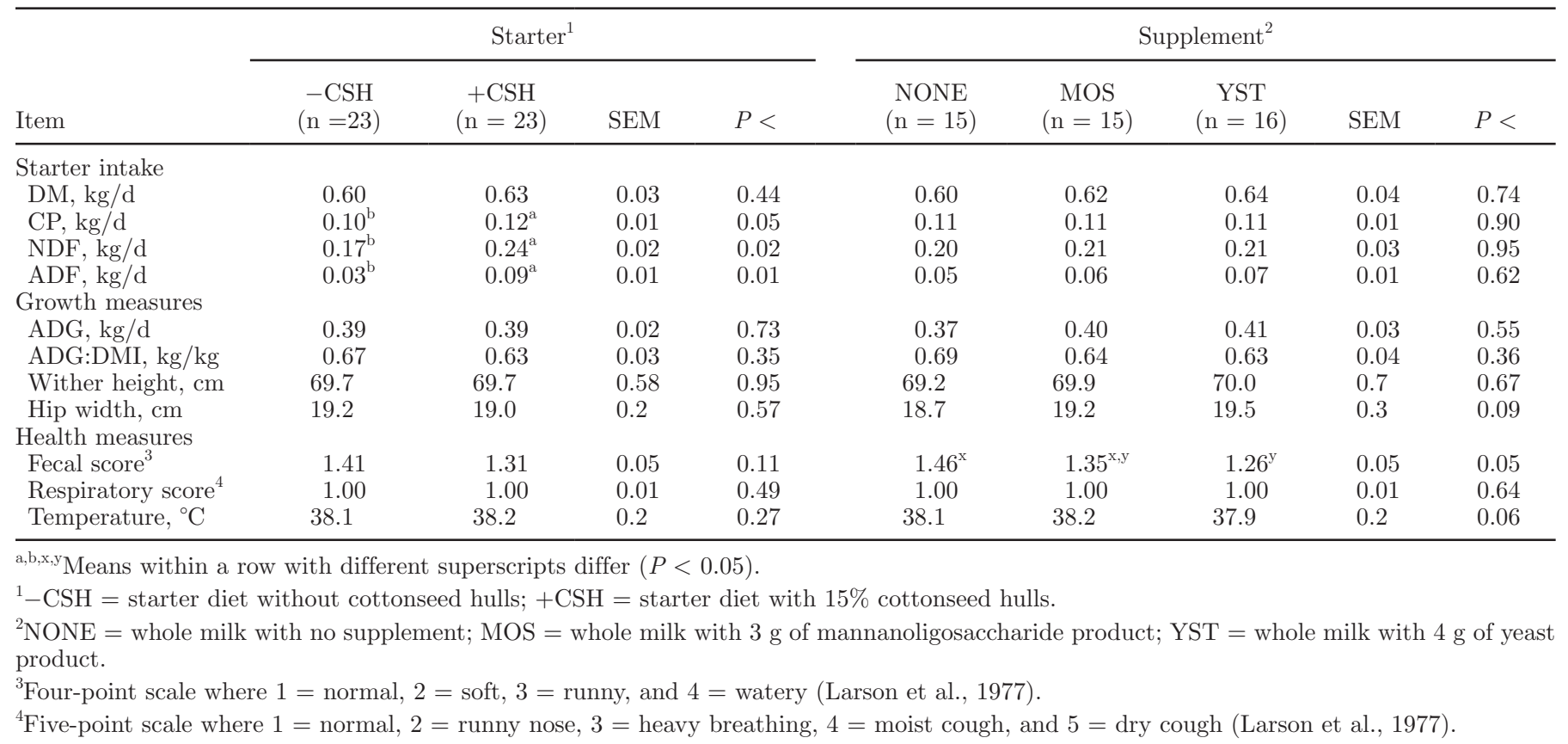




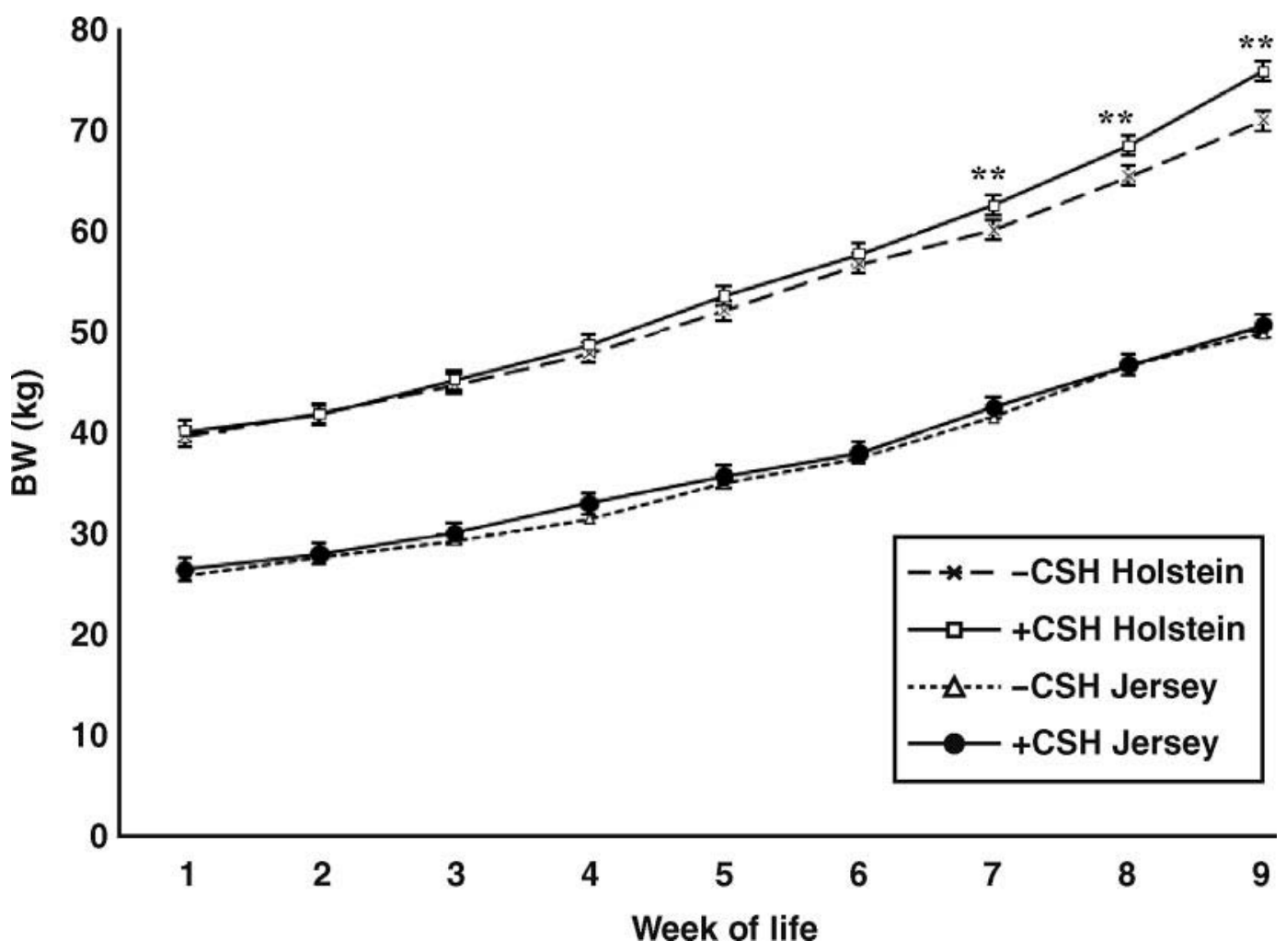

Figure 1. Weekly BW $(\mathrm{kg})$ in Holstein and Jersey calves fed starter diets with $(+\mathrm{CSH})$ or without $(-\mathrm{CSH})$ cottonseed hulls. **Holstein calves fed $+\mathrm{CSH}$ had greater BW than Holstein calves fed $-\mathrm{CSH}$ in wk 7,8 , and $9(P<0.01)$.

1 or $2 \%$ yeast culture to calf starter. Heinrichs et al. (2003) showed that the addition of a mannanoligosaccharide product $(4 \mathrm{~g} / \mathrm{d})$ to milk replacer improved fecal scores using a system that included measurements of fecal fluidity, scours severity, and fecal consistency.

There were no differences observed due to supplement addition in respiratory score or average body temperature in both Holstein and Jersey calves. However, there was a tendency $(P=0.06)$ for a difference in average body temperature in Jersey calves as a result of supplement addition (Table 4). Seymour et al. (1995) reported decreased incidence of elevated body temperatures in calves when $1 \%$ brewer's yeast was supplemented to a calf starter.

\section{Rumen Development Measures in Holstein Calves}

In the euthanized Holstein calves $(\mathrm{n}=12)$, there were no significant differences in molar proportions of acetate, propionate, butyrate, isobutyrate, or isovalerate, or in the acetate:propionate ratio as a result of either starter type or supplement addition (Table 5). Calves fed MOS or YST had greater concentrations of valerate compared with calves fed NONE. Quigley et al. (1992b) reported increased molar concentrations of acetate and butyrate as well as decreased concentrations of propi- onate, but reported no differences in concentrations of valerate in ruminal fluid samples collected $4 \mathrm{~h}$ postfeeding in calves fed a yeast culture supplement. However, Harrison et al. (1988) reported an increase in valerate concentration, accompanied by a decrease in acetate and increase in propionate concentrations, when lactating cows were fed a yeast culture supplement.

Calves that were fed +CSH had narrower papillae than calves fed - CSH, without effect on papillae length, denseness, or SAR (Table 5). There were no effects of supplement addition on papillae length, width, denseness, or SAR. Anderson et al. (1982) reported that Holstein calves at $84 \mathrm{~d}$ of age had longer papillae and more papillae per centimeter squared when fed a starter containing $25 \%$ whole cottonseed compared with calves fed a starter containing no whole cottonseed. Lesmeister et al. (2004) observed no differences in papillae length, papillae width, or rumen wall thickness in Holstein calves that were euthanized at 35 or $42 \mathrm{~d}$ of age and fed 0,1 , or $2 \%$ yeast culture in starter diets. In the current study, the supplements were delivered as part of the milk, which may have passed directly to the abomasum resulting in little or no ruminal effects.

It is generally accepted that papillary development is more dependent on VFA stimulation than on physical stimulation from fiber (Harrison et al., 1960). Calves 
Table 5. Rumen papillae and VFA measures in Holstein calves fed starter diets with or without cottonseed hulls and milk with or without supplements.

\begin{tabular}{|c|c|c|c|c|c|c|c|c|c|}
\hline \multirow[b]{2}{*}{ Item } & \multicolumn{4}{|c|}{ Starter $^{1}$} & \multicolumn{5}{|c|}{ Supplement $^{2}$} \\
\hline & $\begin{array}{c}-\mathrm{CSH} \\
(\mathrm{n}=6)\end{array}$ & $\begin{array}{c}+\mathrm{CSH} \\
(\mathrm{n}=6)\end{array}$ & SEM & $P<$ & $\begin{array}{l}\text { NONE } \\
(\mathrm{n}=4)\end{array}$ & $\begin{array}{c}\text { MOS } \\
(\mathrm{n}=4)\end{array}$ & $\begin{array}{c}\text { YST } \\
(\mathrm{n}=4)\end{array}$ & SEM & $P<$ \\
\hline \multicolumn{10}{|c|}{ Rumen papillae measures } \\
\hline Length, mm & 2.25 & 2.34 & 0.53 & 0.91 & 2.47 & 2.69 & 1.73 & 0.65 & 0.59 \\
\hline Width, mm & $0.41^{\mathrm{a}}$ & $0.32^{\mathrm{b}}$ & 0.02 & 0.01 & 0.39 & 0.34 & 0.36 & 0.02 & 0.28 \\
\hline Denseness, $\mathrm{n} / \mathrm{cm}^{2}$ & 36.5 & 48.4 & 4.9 & 0.14 & 48.6 & 34.1 & 44.6 & 6.02 & 0.28 \\
\hline Acetate & 42.6 & 43.2 & 1.2 & 0.76 & 43.5 & 42.4 & 42.8 & 1.5 & 0.87 \\
\hline Propionate & 38.6 & 40.3 & 3.4 & 0.73 & 43.1 & 39.3 & 35.8 & 4.1 & 0.50 \\
\hline Butyrate & 12.0 & 9.3 & 2.0 & 0.38 & 8.5 & 9.8 & 13.7 & 2.4 & 0.34 \\
\hline Isobutyrate & 0.43 & 0.83 & 0.27 & 0.33 & 0.44 & 0.76 & 0.69 & 0.33 & 0.77 \\
\hline Valerate & 5.69 & 4.94 & 0.49 & 0.32 & $3.71^{\mathrm{y}}$ & $6.41^{\mathrm{x}}$ & $5.83^{\mathrm{x}}$ & 0.60 & 0.04 \\
\hline Isovalerate & 0.73 & 1.41 & 0.48 & 0.36 & 0.72 & 1.33 & 1.17 & 0.59 & 0.76 \\
\hline Acetate:propionate & 1.17 & 1.10 & 0.14 & 0.76 & 1.02 & 1.10 & 1.29 & 0.17 & 0.56 \\
\hline
\end{tabular}

${ }^{\mathrm{a}, \mathrm{b}, \mathrm{x}, \mathrm{y}}$ Means within a row with different superscripts differ $(P<0.05)$.

${ }^{1}-\mathrm{CSH}=$ starter diet without cottonseed hulls $;+\mathrm{CSH}=$ starter diet with $15 \%$ cottonseed hulls.

${ }^{2} \mathrm{NONE}=$ whole milk with no supplement; MOS $=$ whole milk with $3 \mathrm{~g}$ of mannanoligosaccharide product; YST = whole milk with $4 \mathrm{~g}$ of yeast product.

${ }^{3} \mathrm{SAR}=$ surface area ratio $=($ average surface area of papillae $) \times($ average papillae denseness $)$. Surface area of papillae $\left(\mathrm{cm}^{2}\right)=2 \times \mathrm{r} \times \pi \times \mathrm{L}$ $+\pi \times \mathrm{r}^{2}$, where $\mathrm{r}=$ papilla radius (width $/ 2$ ) in centimeters and $\mathrm{L}=$ papilla length in centimeters.

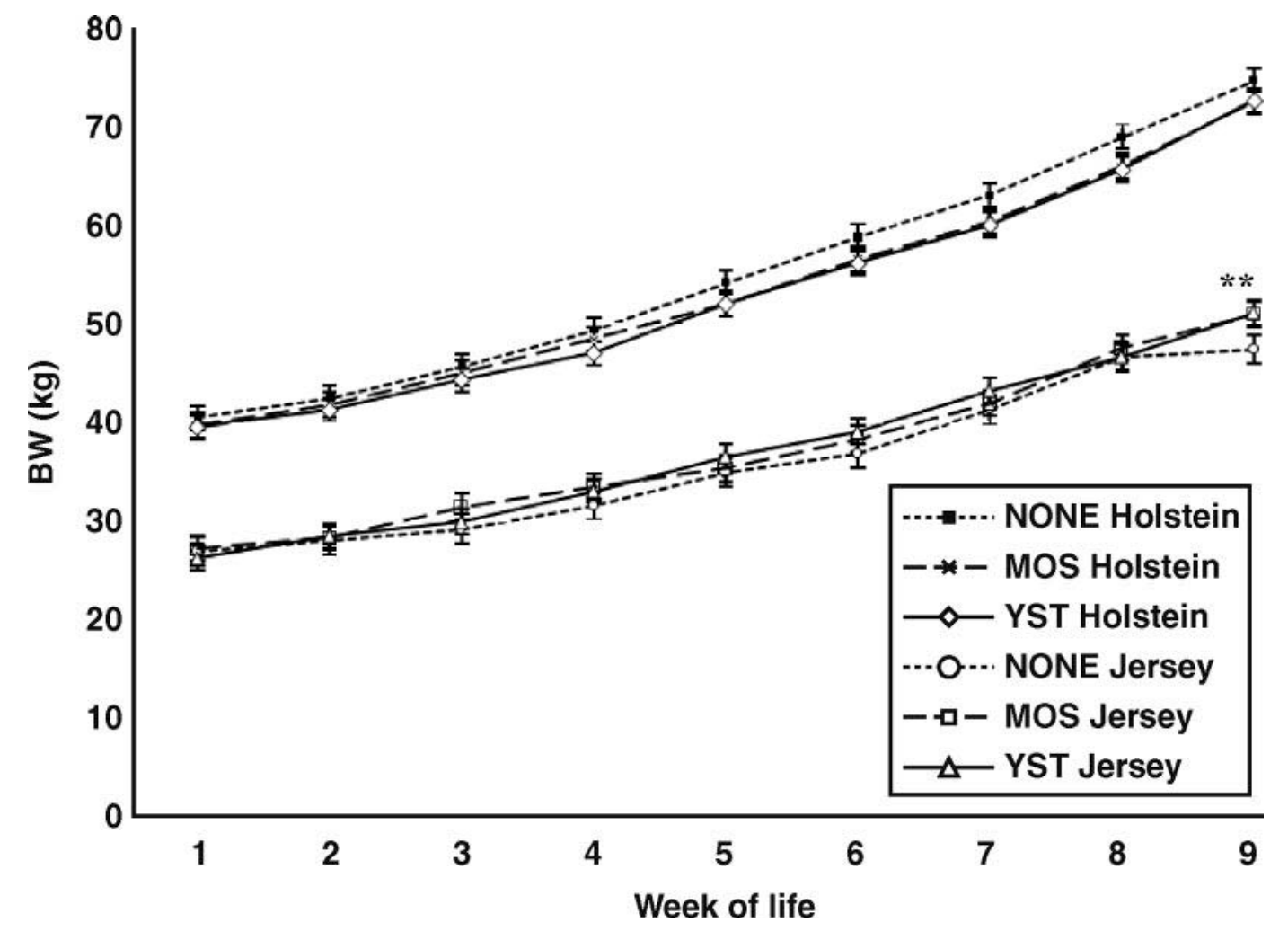

Figure 2. Weekly BW (kg) in Holstein and Jersey calves fed whole milk with no supplement (NONE), 3 g of mannanoligosaccharide product (MOS), or $4 \mathrm{~g}$ of yeast product (YST). ${ }^{* *}$ Jersey calves fed MOS or YST had greater BW than Jersey calves fed NONE in wk $9(P<0.01)$. 
given VFA solutions had greater papillae development than those given inert bulk (Flatt et al., 1958). Because there were no major differences in VFA concentrations and the increased DMI in calves fed $+\mathrm{CSH}$ can be attributed to intake of $\mathrm{CSH}$, changes in papillae width appeared to be the result of CSH intake.

\section{Breed Comparison}

Growth and intake comparisons were made for Holsteins and Jerseys located at DEU (Table 2). Holsteins had a greater average BW, starter DMI, and total DMI but a lower total DMI as a percentage of BW compared with Jerseys $(P<0.01)$. Although total DMI as a percentage of BW was lower in the Holsteins, DMI as a percentage of metabolic $\mathrm{BW}\left(\mathrm{BW}^{0.75}\right)$ was not different between breeds. Although ADG was greater for Holsteins $(P<0.01)$, FE was similar across breeds $(P=0.94)$. Metabolic BW and ADG calculated using $\mathrm{BW}^{0.75}$ were greater in Holsteins compared with Jerseys (Table 2).

Whitaker et al. (1957) noted differences in intake and growth between these 2 breeds such that Holsteins had greater hay consumption and gains than Jersey calves. According to Macleod et al. (1970), when Holstein and Jersey calves were fed the same quantity of milk, Holstein calves had improved starter intake, hay intake, and feed efficiency. Furthermore, ADG was greater for Holsteins compared with Jerseys $(0.71$ vs. $0.46 ; P<$ 0.01 ), but when compared as a percentage of initial $\mathrm{BW}^{0.75}$, there was no breed difference (Macleod et al., 1970).

\section{CONCLUSIONS}

Cottonseed hull addition to a low-fiber calf starter mix increased DMI, ADG, and postweaning BW in Holstein calves. Feeding CSH also resulted in some differences in rumen papillae development and improvement in fecal scores. This study indicated that MOS or YST supplementation in milk may be beneficial to Jersey calves. Measurements of fecal scores, respiratory scores, and body temperature indicated that calves on all treatments in this study were generally healthy, which may have influenced the results of the study. Overall, Holstein calves responded to CSH feeding but not MOS or YST addition, whereas Jersey calves responded to MOS or YST addition but not CSH feeding. In a direct breed comparison, FE was similar for Holstein and Jersey calves.

\section{REFERENCES}

Anderson, M. J., M. Khoyloo, and J. L. Walters. 1982. Effect of feeding whole cottonseed on intake, body weight, and reticulorumen development of young Holstein calves. J. Dairy Sci. 65:764-772.
AOAC. 1990. Official Methods of Analysis. Vol. I. 14th ed. AOAC Int., Arlington. VA.

Burkey, T. E., S. S. Dritz, J. C. Nietfeld, B. J. Johnson, and J. E. Minton. 2004. Effect of dietary mannanoligosaccharide and sodium chlorate on the growth performance, acute-phase response, and bacterial shedding of weaned pigs challenged with Salmonella enterica serotype Typhimurium. J. Anim. Sci. 82:397-404.

Enjalberta, F., J. E. Garrett, R. Moncoulonc, C. Bayourthe, and P. Chicoteau. 1999. Effects of yeast culture (Saccharomyces cerevisiae) on ruminal digestion in non-lactating dairy cows. Anim. Feed Sci. Technol. 76:195-206.

Flatt, W. P., R. G. Warner, and J. K. Loosli. 1958. Influence of purified materials on the development of the ruminant stomach. J. Dairy Sci. 41:1593-1600.

Fonty, G., and F. Chaucheyras-Durand. 2006. Effects and modes of action of live yeasts in the rumen. Biologia 61:741-750.

Harrison, G. A., R. W. Hemken, K. A. Dawson, R. J. Harmon, and K. B. Barker. 1988. Influence of addition of yeast culture supplement to diets of lactating cows on ruminal fermentation and microbial populations. J. Dairy Sci. 71:2967-2975.

Harrison, H. N., R. G. Warner, E. G. Sandler, and J. K. Loosli. 1960. Changes in the tissue and volume of the stomachs of calves following the removal of dry feed or consumption of inert bulk. J. Dairy Sci. 43:1301-1312.

Heinrichs, A. J. 2005. Rumen development in the dairy calf. Adv. Dairy Technol. 17:179-187.

Heinrichs, A. J., C. M. Jones, and B. S. Heinrichs. 2003. Effects of mannan oligosaccharide or antibiotics in neonatal diets on health and growth of dairy calves. J. Dairy Sci. 86:4064-4069.

Hill, S. R., B. A. Hopkins, S. Davidson, S. M. Bolt, D. E. Diaz, C. Brownie, T. Brown, G. B. Huntington, and L. W. Whitlow. 2005. Technical note: Technique for dissection and analysis of the rumen in young calves. J. Dairy Sci. 88:324-326.

Larson, L. L., F. G. Owen, J. L. Albright, R. D. Appleman, R. C. Lamb, and L. D. Muller. 1977. Guidelines towards more uniformity in measuring and reporting calf experimental data. J. Dairy Sci. 60:989-991.

Lesmeister, K. E., A. J. Heinrichs, and M. T. Gabler. 2004. Effects of supplemental yeast (Saccharomyces cerevisiae) culture on rumen development, growth characteristics, and blood parameters in neonatal dairy calves. J. Dairy Sci. 87:1832-1839.

Macleod, G. K., E. B. Burnside, and D. G. Grieve. 1970. Growth of Holstein and Jersey calves in response to four feeding programs in a breed-by-ration interaction study. J. Dairy Sci. 53:1270-1274.

Miller, W. J., Y. G. Martin, and P. R. Fowler. 1969. Effects of addition of fiber to simplified and to complex starters fed to young dairy calves. J. Dairy Sci. 52:672-676.

Murdock, F. R., and R. W. Wallenius. 1980. Fiber sources for complete calf starter rations. J. Dairy Sci. 63:1869-1873.

NRC. 2001. Nutrient Requirements of Dairy Cattle. 7th ed. Natl. Acad. Sci., Washington, DC.

Quigley, J. D. III, T. M. Steen, and S. I. Boehms. 1992a. Postprandial changes of selected blood and ruminal metabolites in ruminating calves fed diets with or without hay. J. Dairy Sci. 75:228-235.

Quigley, J. D. III, L. B. Walls, H. H. Dowlen, and R. N. Heitmann. 1992b. Sodium bicarbonate and yeast culture effects on ruminal fermentation, growth, and intake in dairy calves. J. Dairy Sci. 75:3531-3538.

Seymour, W. M., J. E. Nocek, and J. Siciliano-Jones. 1995. Effects of a colostrum substitute and of dietary brewer's yeast on the health and performance of dairy calves. J. Dairy Sci. 78:412-420.

Spring, P., C. Wenk, K. A. Dawson, and K. E. Newman. 2000. The effects of dietary mannanoligosaccharides on cecal parameters and the concentrations of enteric bacteria in the ceca of Salmonellachallenged broiler chicks. Poult. Sci. 79:205-211.

Stobo, I. J. F., J. H. B. Roy, and H. J. Gaston. 1966. Rumen development in the calf 1 . The effects of diets containing different proportions of concentrates to hay on rumen development. Br. J. Nutr. 20:171-188.

Swanson, K. S., C. M. Grieshop, E. A. Flickinger, L. L. Bauer, H.-P. Healy, K. A. Dawson, N. R. Merchen, and G. C. Fahey Jr. 2002. 
Supplemental fructooligosaccharides and mannanoligosaccharides influence immune function, ileal and total tract nutrient digestibilities, microbial populations and concentrations of protein catabolites in the large bowel of dogs. J. Nutr. 132:980-989.

Van Horn, H. H., B. Harris Jr., M. J. Taylor, K. C. Bachman, and C. J. Wilcox. 1984. By-product feeds for lactating dairy cows: Effects of cottonseed hulls, sunflower hulls, corrugated paper, peanut hulls, sugarcane bagasse, and whole cottonseed with additives of fat, sodium bicarbonate, and Aspergillus oryzae product on milk production. J. Dairy Sci. 67:2922-2938.

Van Horn, H. H., M. B. Olayiwole, C. J. Wilcox, B. Harris, and J. M. Wing. 1976. Effects of housing, milk feeding management, and ration formulation on calf growth and feed intake. J. Dairy Sci. 59:924-929.

Whitaker, R. T., W. J. Miller, J. L. Carmon, and H. L. Dalton. 1957. Influence of level and source of crude fiber in calf starters on weight and feed consumption. J. Dairy Sci. 40:887-892. 